\title{
The Influence of Balanced Nutrition Extension through Poster Media on the Improvement of Knowledge and Change Attitude
}

\author{
Oslida Martony \\ Politeknik Kesehatan Medan, Indonesia \\ Email: oslida64@gmail.com
}

\begin{abstract}
The purpose of this study was to determine the Effect of Balanced Nutrition Counseling through Poster Media on Knowledge Enhancement and Attitude Change of School Children in MIN Medan Senembah Kec. Tanjung Morawa. This research is an experimental study using design before and after the intervention using an external comparison group. The population was 346 students in grades 3.4 and 5-the research sample of 78 student samples. Data collected are before and after knowledge, before and after attitude. The method uses a questionnaire. Data collection is done by questionnaire form. Data analysis uses Paired Sample T-Test and Independent T-Test tests. The results obtained by the common knowledge before counseling in the experimental group are 62.87, and in the comparison group is 49.45 . The average post-counseling knowledge in the experimental group was 76.17 , and in the comparison group was 61.12. The average attitude before in the experimental group was 68.31 and in the comparison group 62.97. The average attitude after the experimental group was 73.85, and the comparison group was 68.95. There were significant differences in knowledge and attitudes before and after counseling ( $p$-value $=0.000>0.05)$. There were no differences in knowledge and attitudes between the experimental and comparison groups ( $p$ value $=0.490>0.05$ )
\end{abstract}

Keywords: Balanced Nutrition Counseling, Poster Media, Knowledge, Attitude, Elementary School Children.

\section{A. INTRODUCTION}

Nutrition problems in Indonesia are increasingly complex. Healthy living patterns, including a balanced diet with nutrition, are among the main factors in the complexity of nutrition problems in Indonesia. Therefore, the community needs to get clear and adequate information about a balanced diet with nutrition, including eating a variety of foods (eating vegetables and fruit), clean living behavior, carrying out physical activities, and routinely weighing as a component of a balanced lifestyle (Mulyani et al., 2016).

Nutrition programs in groups of school children have a broad impact that affects not only the health, nutrition, and education aspects of the present but also directly affects the quality of human resources in the future. School children are strategic targets in improving community nutrition (Mulyani et al., 2016).

Primary school-age children (6-12 years old) are the age group who are still experiencing growth and development and need adequate nutritional needs and are 
suitable to support their growth and development. Still, at this time, children have poor eating habits so that many need for substances nutrition that cannot be fulfilled optimally. Inappropriate nutrient intake in childhood can lead to various nutritional problems and impact their learning achievement (Yahmin \& Dharmawan, 2012).

Based on basic health research results in 2013, nationally, the prevalence of thinness (according to BMI / U) in children aged 5-12 years was 11.2 percent, consisting of 4.0 percent very thin and 7.2 percent thin. The problem of fat in children aged 5-12 years is still high at 18.8 percent, 2 of which consist of fat 10.8 percent and very fat (obese) 8.8 percent.

According to the Basic Health Research in 2010, it was found that the population consuming food below 70\% of the Recommended Nutrition Adequacy Rate (RDA) was $40.6 \%$. This situation is often found in school-age children, 41.2\%. The 2013 Riskesdas data in North Sumatra figures about proper handwashing behavior that is $32.9 \%$, for the proportion of physical activity classified as less active in general that is $23.5 \%$, the proportion of vegetable and fruit-eating behavior is $93.5 \%$ but for the proportion food consumption patterns are at risk of getting the highest proportion of $62.5 \%$.

Meanwhile, according to the 2007 North Sumatra Riskesdas data, in Deli Serdang Regency, the percentage of the ten-year-old population who lacked vegetables and fruits was $95.2 \%$. This condition is in line with the findings of the Individual Food Consumption Survey (SKMI) in the 2014 Total Diet Study (SDT) that the population consumption of vegetables and fruit and all its preparations is still low (Balitbangkes, 2014).

Nutritional problems in elementary school children usually begin with a lack of energy and protein intake below the minimum requirements (Riskesdas, 2010). Also, the prevalence of eating fruits and vegetables is still relatively high; physical activity is still relatively low (Riskesdas, 2007).

On the other hand, most of the time this child is used a lot of activities outside the home, which is around 3-6 hours at school, a few hours to play, exercise and so on so that children need more energy. More time spent with friends can affect a child's eating schedule, even his diet. Not to mention because of the wrong eating pattern in the previous age, which is still carried away at this age; for example, children prefer snacks, less fiber food, like eating and drinking sweet and so on. As a result, children do not get a balanced and safe nutritious diet, impacting low body weight (BB) due to malnutrition and often sick. It can also occur due to excess energy intake, always eating, and drinking energy-dense so that children experience obesity problems (obesity) (Mulyani et al., 2014).

According to WHO in Supariasa (2014), nutrition education is a planned effort to improve nutritional status through behavioral changes related to food and nutrition. Behavior changes by first being given a reinforcement in the form of information about something that can change behavior in advance. Prevention is done early to reduce the 
prevalence rate and to create better human resources. One of the usual nutrition improvement programs is through counseling.

Nutrition counseling in schools has several advantages, including that children have an open mind compared to adults, and the knowledge received can be the basis for their eating habits. Improving the nutrition of elementary school children, in particular, is a strategic step because its impact is directly related to the achievement of quality human resources (Ministry of Health of the Republic of Indonesia, 2005).

Nutrition counseling given to elementary school-age children is sought to be provided through attractive media so that the delivery of material can be received more quickly. One of the media that will be used is printed media; one of them is the poster. The superiority of printed media images through balanced nutrition posters will clarify a problem by looking at clear images and following the subject matter. Image media can also lead to diverse student creativity in expressing. Students will be more explicit about a subject or material that will be delivered (Februhartanty, 2004). This is in line with Suiraoka's (2010) research that there is a significant effect of better nutrition knowledge on respondents given nutrition counseling with the media compared to respondents who were not given nutrition education without using media.

Posters are a visual combination of robust designs, colors, and messages to capture the attention of passers-by but long enough to instill passers-by's attention but long enough to instill meaningful ideas in their memories (Sudjana \& Rivai, 2010). According to Susilana \& Riana (2009), the poster is a visual combination that is clear, striking, and interesting, attracting the attention of passers-by. Based on the opinion above, researchers can conclude that poster media, in general, is a written message either in the form of pictures or writing intended to attract many people's attention.

\section{B. METHOD}

This type of research is a Research Experiment with the design of the design. Before and After the Intervention using an External Comparison Group (Notoatmodjo, 2010). The form of this design is as follows:

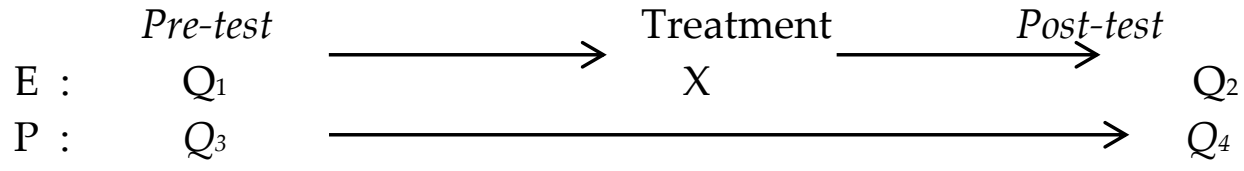

\section{Figure 1. Form of Design Before and after intervention using an External Comparative Group.}


Information:

$\mathrm{Q}_{1}$ : Pre-test, i.e., measurement of knowledge and attitudes before treatment

$X$ : The intervention given is the Balanced Nutrition Poster Media and provides balanced nutrition counseling as an introduction to the message information in the Poster content.

$\mathrm{Q}_{2}$ : Post-test, i.e., measurement of knowledge and attitude after treatment

$\mathrm{Q}_{3}$ : Pre comparison group test

$\mathrm{Q}_{4}$ : Post-test comparison group

The sample in this study amounted to 78 students in grades 3.4 and 5 of the Madrasah Ibtida'iyah Negri (MIN) school in Tanjung Morawa Subdistrict, Medan Senembah Village, Tanjung Morawa Subdistrict in the 2017-2018 academic year, totaling 346 people. Data was collected using a questionnaire that was filled in by the respondent himself.

Based on the type of data collected in this study, including primary and secondary data. Primary data is collected directly by the researcher consisting of Sample identity data, Knowledge data, and attitudes before and after poster presentation. Secondary data, namely data obtained based on information collected by the school, which includes research and student data.

\section{RESULT AND DISCUSSION}

1. Differences in Knowledge Score before and after Intervention between the Experiment Group and the Comparison Group

Table 1. Experiment Group Knowledge

\begin{tabular}{|c|c|c|c|c|}
\hline \multirow{2}{*}{$\begin{array}{c}\text { Group of } \\
\text { Experiment }\end{array}$} & & Mean & N & Std. Deviation \\
\cline { 2 - 5 } & Pre-Test & 62.87 & 78 & 15.898 \\
\cline { 2 - 5 } & Post-Test & 76.17 & 78 & 14.259 \\
\hline${ }^{*} p=0,000$
\end{tabular}

Table 1 shows the experimental group shows the results between changes in knowledge before and after almost no difference, namely 15.898 for the knowledge score before and 14,259 for the knowledge score. With a difference of 1.639. Statistical test results obtained $p$-value $=0.000>0.05$ mean that at alpha $5 \%$, there is a significant difference in the average percentage score of knowledge about balanced nutrition.

Table 2. Comparative Group Knowledge

\begin{tabular}{|l|c|r|r|r|}
\hline \multirow{2}{*}{$\begin{array}{c}\text { Group of } \\
\text { Comparative }\end{array}$} & & Mean & \multicolumn{1}{c|}{ N } & Std. Deviation \\
\cline { 2 - 5 } & Pre-Test & 49.45 & 78 & 15.456 \\
\cline { 2 - 5 } & Post-Test & 61.12 & 78 & 14.752 \\
\hline${ }^{*} p=0,000$
\end{tabular}


Table 2 shows the comparison group shows the results between changes in knowledge before and after almost no difference, that is, 15,456 for the knowledge score before and 14.752 for the knowledge score after. The results above show that the average percentage of respondents' knowledge with the knowledge score before is higher than the knowledge score after a difference of 704 . The statistical test results obtained p-value $=0.000>0.05$ mean that at alpha $5 \%$, there is a significant difference in the average percentage score of knowledge about balanced nutrition.

\section{Difference in Attitude Score before and after Intervention between the Experiment Group and the Comparison Group}

\section{Table 3. Experiment Group Attitude}

\begin{tabular}{|c|l|c|c|c|}
\hline \multirow{2}{*}{$\begin{array}{c}\text { Group of } \\
\text { Experiment }\end{array}$} & & Mean & N & Std. Deviation \\
\cline { 2 - 5 } & Pre-Test & 68.31 & 78 & 6.914 \\
\cline { 2 - 5 } & Post-Test & 73.85 & 78 & 6.758 \\
\hline
\end{tabular}

${ }^{*} p=0,000$

Table 3 shows that in the experimental group, the results between changes in attitude before and after were almost no different, namely 6.914 for attitude scores before and 6.758 for attitude scores after. The results above show that the average percentage of respondents' attitudes with attitude scores before was higher than the attitude scores after a difference of 156. statistical test results obtained p-value $=0.000>$ 0.05 mean that at alpha 5\%, there is a significant difference in the average percent score attitude about balanced nutrition.

\section{Table 4. Comparative Group Attitude}

\begin{tabular}{|l|r|r|r|r|}
\hline \multirow{3}{*}{$\begin{array}{l}\text { Group of } \\
\text { Comparative }\end{array}$} & & Mean & \multicolumn{1}{c|}{ N } & Std. Deviation \\
\cline { 2 - 5 } & Pre-Test & 62.97 & 78 & 7.148 \\
\cline { 2 - 5 } & Post-Test & 68.95 & 78 & 6.287 \\
\hline${ }^{*} p=0,000$
\end{tabular}

Table 4 shows the comparison group shows the results between changes in attitude before and after almost different, namely 7.148 for the attitude score before and 6.287 for the attitude score after. The difference of 861 . statistical test results obtained pvalue $=0.000>0.05$ means that at alpha $5 \%$, there is a significant difference in the average percent score attitudes about balanced nutrition. 


\section{The difference in Mean Change in Knowledge of Balanced Nutrition in the Two Groups}

Table 5. Average Change in Knowledge about Nutrition

\begin{tabular}{|c|l|r|r|r|r|}
\hline Variable & \multicolumn{1}{|c|}{ Group } & $\mathrm{N}$ & \multicolumn{1}{c|}{ Mean } & Std. Deviation & p-value \\
\hline \multirow{2}{*}{ Knowledge } & Experiment & 78 & 13.46 & 12.423 & 0.688 \\
\cline { 2 - 6 } & Control & 78 & 12.09 & 12.335 & \\
\hline
\end{tabular}

Table 5 explains that the average change in knowledge in the experimental group is higher than that of the control group, with a difference of 137 . The statistical test results obtained $\mathrm{p}=0.688<0.05$ mean that at $5 \%$ alpha, there is no significant difference in the average knowledge about balanced nutrition.

\section{Differences in Average Changes in Attitudes about Balanced Nutrition in the Two Groups.}

Table 6. Changes in Attitudes about Nutrition

\begin{tabular}{|l|l|c|c|c|c|}
\hline Variable & Group & $\mathrm{N}$ & Mean & Std. Deviation & p-value \\
\hline \multirow{2}{*}{ Attitude } & Experiment & 78 & 5.59 & 5.936 & 0.445 \\
\cline { 2 - 5 } & Control & 78 & 5.97 & 4.862 & \\
\hline
\end{tabular}

Table 6 explains that the average attitude change in the experimental group is higher than the control group, with a difference of 1.074. Statistical test results obtained $p$-value $=0.445<0.05$ means that at alpha $5 \%$, there is no significant difference in the average attitude about balanced nutrition.

\section{a. The Effect of Balanced Nutrition Counseling through the Media Poster on Increasing the Knowledge of School Children}

The results of the statistical tests in the experimental group were $69.52 \%$. In the comparison group, there were $55.28 \%$ with a p-value of 0.000 . There was an influence of counseling about balanced nutrition on knowledge between the comparison group not given balanced nutrition counseling with the experimental group being counseled. The information provided in counseling can increase students' knowledge, the more often they get information about nutrition, the better the knowledge of schoolchildren about balanced nutrition.

Balanced nutrition education is essential to increase knowledge about nutrition for school children. Efforts to improve nutrition knowledge through counseling are the right steps to take and are supported by parties who care about school children. This is in line with Susanti's research, (2015) states that there was a significant increase in knowledge after being given a health education intervention using print media by 
$81.46 \%$. This is because the print media can display images and languages that are easily understood by the target.

According to Hadi et al. (2012), there is an increase in cognitive, affective, and psychomotor after being given health education using comic media. Wahyuni, Sarma, and Pulungan's (2007) research showed a significant relationship between counseling given through mass media and behavior $(\mathrm{p}=0.009)$.

Increased knowledge itself is influenced by several factors, namely, education, personal or other experiences, mass media, and the environment (Notoadmojo, 2012). The influence of education on increasing knowledge is in line with research conducted by Hastuti (2015) about learning which is also included in the concept of education wherefrom the results of his research he found there are significant differences before and after the implementation of balanced nutrition learning in obese students which can be seen from the -value $<0.05$.

There have been several studies that have been conducted relating to the use of posters, including suggesting that counseling with lectures and poster methods can improve the knowledge, attitudes, and actions of postpartum mothers in exclusive breastfeeding in Sait Nihuta Dolok Sanggul District, Humbang Hasundutan District (Astuti, 2013).

\section{b. Effects of Balanced Nutrition Counseling through Poster Media on Changes in Attitudes of School Children}

The results of the statistical test in the experimental group were $71.34 \%$. In the comparison group, there were $65.96 \%$ with a p-value of 0.000 that there was an influence of counseling about balanced nutrition on changes in attitudes between the comparison group who were not given balanced nutrition counseling with the experimental group given counseling.

The results of data processing show an increase in attitudes of school children before, and after being given, the intervention has increased positively.

Nutrition communication with poster media also showed a significant difference in the average increase in attitude scores between the experimental and control groups. Therefore, posters made it easier for students to receive messages and find out the contents of balanced nutrition messages illustrated in the poster.

According to Mubarak (2007), attitudes are not carried from birth but are formed and studied throughout the person's development concerning his object. This study's results are in line with research conducted by Ambarwati et al. (2013) about the effect of leaflet media on exclusive breastfeeding for up to 3 months, which shows the results of differences in behavior between the experimental and the comparison group. 


\section{CONCLUSION}

The average change of knowledge before the intervention in the experimental group was higher than in the comparison group with a difference of 1,639. The average change in attitude after the intervention in the experimental group was higher than in the comparison group with a difference of 861 . There is no significant difference in changes in knowledge about balanced nutrition through poster media between the control group and the comparison group. There is no significant difference in attitudes about balanced nutrition through poster media between the control and comparison groups.

\section{REFERENCES}

1. Aditama, A., Hasyim, A., \& Adha, M. M. (2013). Pengaruh Sikap dan Motivasi Masyarakat terhadap Partisipasi dalam Pelaksanaan Kegiatan Siskamling. Jurnal Kultur Demokrasi, 1(6).

2. Adriani, M., \& Wirjatmadi, B. (2012). Peranan gizi dalam siklus kehidupan. Jakarta: Kencana prenada media group.

3. Alfyan, M. T. (2010). Hubungan Pengetahuan Gizi Dengan Status Gizi Siswa di SMA Harapan 1 Medan. Jurnal Universitas Sumatera Utara. Medan.

4. Almatsier, S. (2013). Prinsip Dasar Ilmu Gizi. Jakarta: Gramedia Pustaka Utama.

5. Ambarwati, R., Muis, S. F., Susantini, P. (2013). Pengaruh Konseling Laktasi Intensif terhadap Pemberian ASI Eksklusif sampai 3 Bulan. Jurnal Gizi Indonesia, 2(1).

6. Azwar, S. (2013). Sikap Manusia Teori dan Pengukurannya. Yogyakarta: Pustaka Pelajar Offset.

7. Daryanto. (2012). Media Pembelajaran. Bandung: Satu Nusa.

8. Djamarah, S. B. (2008). Psikologi Belajar. Jakarta: Rineka Cipta.

9. Februhartanty, J. (2004). Amankah Makanan Jajanan Anak Sekolah di Indonesia?. Accessed September 28, 2014.

10. Hadi, C., Mula, K. Y., \& Rahmah, Z. (2012). Pengaruh Penyuluhan Kesehatan Dengan Media Komik Tanggap DBD Terhadap Peningkatan Pengetahuan dan Sikap Tentang Pencegahan DBD di SDN Banjarejo Ngadiluwih Kabupaten Kediri. Prosiding Seminas, 1(2).

11. Ihsan, F. (2011). Dasar-dasar Kependidikan Komponen MKDK. Jakarta: Rineka Cipta.

12. Kholid, A. (2012). Promosi Kesehatan. Jakarta: Rajawali Pers.

13. Khomsan, A. (2010). Pangan dan Gizi untuk Kesehatan. Jakarta: Gramedia Pustaka Utama.

14. Kusrianto, A. (2007). Pengantar Desain Komunikasi Visual. Yogyakarta: Andi Offset.

15. Maryani, I. D. (2008). Hubungan antara Status Gizi dengan Prestasi Belajar Siswa Sd Negeri Tangkil III di Sragen (Doctoral Dissertation, Universitas Muhammadiyah Surakarta). 
16. Machfoedz, I., \& Suryani, E. (2003). Pendidikan Kesehatan Bagian dari Promosi Kesehatan. Yogyakarta: Fitramaya.

17. Ministry of Health of the Republic of Indonesia. (2014). Pedoman Gizi Seimbang. Jakarta: Direktur Jenderal Bina Gizi dan KIA.

18. Ministry of Health of the Republic of Indonesia. (2007). Laporan Hasil Riset Kesehatan Dasar (RISKESDAS). Jakarta: Ministry of Health of the Republic of Indonesia.

19. Ministry of Health of the Republic of Indonesia. (2010). Laporan Hasil Riset Kesehatan Dasar (RISKESDAS). Jakarta: Ministry of Health of the Republic of Indonesia.

20. Ministry of Health of the Republic of Indonesia. (2016). Pedoman Umum Gizi Seimbang Tahun 2014. Jakarta: Ministry of Health of the Republic of Indonesia.

21. Moehji, S. (2003). Ilmu Gizi. Jakarta: Papas Sinar Sinanti.

22. Mubarak, C. (2009). Teori dan Aplikasi Ilmu Kesehatan Masyarakat, Pendidikan Kesehatan, Konsep Perilaku dan Perilaku Kesehatan. Jakarta: Salemba Medika.

23. Musfiqon. (2012). Pengembangan Media dan Sumber Pembelajaran. Jakarta: Prestasi Pustakarya.

24. Notoatmodjo, S. (2003). Pendidikan dan Perilaku Kesehatan. Jakarta: Rineka Cipta.

25. Notoatmodjo, S. (2003). Ilmu Kesehatan Masyarakat. Jakarta: Rineka Cipta.

26. Notoatmodjo, S. (2003). Ilmu Kesehatan Masyarakat (Prinsip-Prinsip Dasar). Jakarta: Rineka Cipta.

27. Notoatmodjo, S. (2007). Promosi Kesehatan dan Ilmu Perilaku. Jakarta: Rineka Cipta.

28. Notoatmodjo, S. (2010). Metodologi Penelitian Kesehatan. Jakarta: Rineka Cipta.

29. Notoatmodjo, S. 2011. Kesehatan Masyarakat. Jakarta: Rineka Cipta.

30. Notoatmodjo, S. (2012). Promosi Kesehatan dan Perilaku Kesehatan. Jakarta: Rineka Cipta.

31. Pratiwi, R. (2013). Pengaruh Pemahaman Materi Hak Asasi Manusia Terhadap Sikap Kemanusiaan Siswa Kelas VII di SMP Negeri 2 Hulu Sungka Kabupaten Lampung Utara Tahun Pelajaran 2012/2013. Universitas Lampung.

32. Sudjana, N., \& Rivai, A. (2002). Media Pengajaran. Bandung: Sinar Baru Algensindo.

33. Susilana, R., \& Riyana, C. (2008). Media Pembelajaran: Hakikat, Pengembangan, Pemanfaatan, dan Penilaian. Jakarta: Wacana Prima.

34. Setiawan, Y., \& Dharmawan, A. C. (2012). Masalah Gizi pada anak Sekolah Dasar. Retrieved from https://www.lkc.or.id/2012/09/14/masalah-gizi-pada-anak-sekolahdasar/2012.

35. Soetjiningsih. (2012). Perkembangan Anak dan Permasalahannya dalam BukuAjar I Ilmu Perkembangan Anak dan Remaja. Jakarta: Sagungseto.

36. Susanto, M. (2002). Diksi Rupa. Yogyakarta: Kanisius.

37. Wahyuni, E. S., \& Pulungan, I. (2007). Faktor-Faktor yang Berhubungan dengan Perilaku Pembaca dalam Memperoleh Informasi Gaya Hidup Sehat (Studi Kasus Pembaca Tabloid Senior di Kecamatan Bogor Utara). Jurnal Penyuluhan, 3(2). 